\title{
Трансформация семантики термина и этнонима қазақ (قزاق/qazaq/казаx) в Восточном Дешт-и Кыпчаке
}

\author{
Атыгаев Нурлан Адилбекович, Центральный государственный музей Республики Казахстан (Алматы), \\ Государственный историко-культурный музей-заповедник «Сарайшық» (Атыраy); nuratygaev@mail.ru
}

Статья посвящена исследованию термина и этнонима қ̧азақ (казах), являющегося этническим названием основного населения Республики Казахстан. В статье высказывается предположение, что термин қ̧азақ происходит от тюркского глагола қ̧аз'копать, рыть'. Возможно, им первоначально обозначали молодых людей, перешедших к казакованию и живших не в юртах, в отличие от кыпчаков-кочевников, а в домах, которые сами вырыли, выкопали в лесных и горных массивах.

Выделяются следующие этапы развития термина құзақ в Восточном Дешт-и Кыпчаке XIII-XVI вв. 1. C XIII в. до второй половины XIV в., словом құазақ называли неженатых, молодых людей, которые на время рвали связи со своим родственниками и добровольно уходили в отдаленные места, где проходили своеобразную школу выживания. Термин казаклык 'казакование' обозначал обычай «смелости и мужества». 2. Со второй половины XIV в. по 1465 гг., в Восточном Дешт-и Кыпчаке (и в бывшем Чагатайском улусе) словом қ̧азақ в первую очередь называли чингизидов, которые в условиях политической борьбы были вынуждены оставить свои исконные владения и заняться казакованием. Термин казаклык обозначал распространенный в среде чингизидов метод политической борьбы, а также, как и ранее, обычай «смелости и мужества». 3. C 1465 г. до конца XV в., с созданием государства в междуречье Шу и Или, словом құазақ соседи стали называть его население. 4. C конца XV в. до середины XVI в. происходит этнополитическое разделение населения «Узбекского улуса», появляются три этнополитические общности, происхождение которых связано с «Узбекским улусом»- ногаи, узбеки-шибаны и казахи. В этот период термин қ̧азақ был этнополитонимом. 5. С середины XVI в. термины қ̧азақ и алаш стали отражать самоидентификацию населения Казахского ханства, Казахстана, а для соседних народов термин қ̧азақ̧ стал употребляться как этноним для обозначения его населения.

Ключевые слова: этноним, политоним, қ̧азақ (казах), «казаклык»/казакование, Казахское ханство, Керей-хан, Жанибек-хан, исторические источники, «Тарих-и Рашиди»

\section{TRANSFORMATION OF THE SEMANTICS OF THE TERM AND ETHNONYM KAZAKH (قزاق) /QAZAQ/KAZAKH) IN THE EAST DESHT-I KYPCHAK}

Nurlan A. Atygayev, Central State Museum of the Republic of Kazakhstan (Almaty), The State Historical and Cultural Museum-Reserve «Saraychik»(Atyrau); nuratygaev@mail.ru

The article is devoted to the study of the term and ethnonym Qazaq/Kazakh, which is the ethnic name of the main population of the Republic of Kazakhstan. The article suggests that the term Qazaq comes from the Turkic verb qaz- 'dig'. Perhaps this term meant young Turkic people who switched to qazaqliq (free, or qazaq style of living), and, unlike the nomadic Kipchaks, used to live not in yurts, but in dugouts that they themselves dug up in forest and mountain ranges.

The following stages in the development of the term qazaq/Qazaq in East Desht-i Qipchaq of the $13^{\text {th }}-14^{\text {th }}$ centuries are highlighted. 1 . In the $13^{\text {th }}$ - the $2^{\text {nd }}$ half of the $14^{\text {th }}$ century, the word qazaq was applied to unmarried young people who temporarily broke off ties with their relatives and went to remote places, where they passed a kind of a school of survival. The term qazaqliq denoted the custom of "bravery and courage". 2. From the $2^{\text {nd }}$ half of the $14^{\text {th }}$ century to 1465 , in East Desht-i Qipchaq (and in the former Chagatai ulus) the word qazaq was primarily applied to Chingizids, who in the conditions of political struggle were forced to abandon their original possessions and take up the qazaqliq. The term qazaqliq denoted the method of political struggle, widespread among the Chingizids, as well as the custom of "bravery and courage" as before. 3 . From 1465 to the end of the $15^{\text {th }}$ century, with the foundation of an independent state between Shu and Ili rivers, their neighbors began to call its subjects Qazaqs, and the term became a politonym. 4. From the end of the $15^{\text {th }}$ century until the middle of the $16^{\text {th }}$ century, the ethno-political division of Uzbek Ulus took place. Three ethnopolitical communities originating from Uzbek Ulus emerged: Nogai, Shiban Uzbeks, and Qazaqs. During this period, the term qazaq became an ethno-politonym. 5. From the middle of the $16^{\text {th }}$ century till today, the terms Qazaq/Kazakh and Alash began to reflect the selfidentification of the population of the Kazakh Khanate, Kazakhstan, and the term Qazaq/Kazakh has acquired an ethnic meaning and started to be used as an ethnonym to refer to the population of the Kazakh Khanate.

Keywords: ethnonym, politonym, Qazaq/Kazakh, qazaqliq, Kazakh Khanate, Kerey Khan, Janibek Khan, historical sources, “Tarih-i Rashidi”

Статья подготовлена в рамках реализации проектов ГФ №АР09562452, ГФ №АР09261233. 
Этноним қ̧азақ (قزاق)qazaq/казаx) является этническим названием основного населения Республики Казахстан. На сегодняшний день численность казахов в мире приблизилась к 19 миллионам человек, из которых более шести миллионов живут за пределами Казахстана.

Исследование истории термина и этнонима қ̧азақ имеет свою богатую историографическую традицию. Более двухсот лет ученые пытаются выяснить происхождение и раскрыть семантику этого слова. Первые научные попытки в этом направлении стали предприниматься исследователями Российской империи еще в начальный период их знакомства с казахами. Вопрос о происхождении казахов и их этнического самоназвания поднимали в своих работах В. Н. Татищев, П. И. Рычков, И. Фишер, А. И. Левшин и др. Данный вопрос не остался без внимания и со стороны ученых советского периода - В. В. Бартольда, А. Н. Самойловича и др. Естественно, интересовала эта проблема и казахских исследователей XIX - начала XX в.: Ч. Ч. Валиханова, А. Н. Букейханова, М. Т. Тынышпаева, С. Ж. Асфендиярова и др. (Историографию проблемы см.: [Ибрагимов 1960: 67-71; Кляшторный, Султанов 1992: 250-258; Кумеков 1997; История Казахстана 1997: 32-40]). Рассматривая этот вопрос, М. Т. Тынышпаев и С. Ж. Асфендияров пришли к мнению, что искать значение слова құзақ бесполезно [Тынышпаев 1993: 124; Асфендиаров 1935: 71].

Тюркологи Запада также обращали свое внимание на вопрос о происхождении термина қ̧азақ. Хорошо известны посвященные этой проблематике работы немецкого исследователя Аннемари фон Габен и американского востоковеда О.И. Прицака, которые искали истоки слова қазақ в глаголах qazи qazyan-, известных из древнетюркских надписей VIII в. [Gabain 1960: 161—67; Pritsak 2006: 237—243].

В целом в течение XVIII-XXI вв. было предложено множество различных версий — от научных до выдуманных «диких» этимологий относительно происхождения и семантики термина и этнонима қ̧азақ. По подсчетам академика А. Т. Кайдара, высказаны около 150 этимологических и этнолингвистических предположений об этом слове [Қайдар 2008: 345]. «Многочисленные попытки выяснить происхождение этнонима превратились в состязание на лингвистическое остроумие. Безуспешность их породила скептицизм в отношении способностей филологов решить вопрос», - отмечал еще в советский период В. П. Юдин [Юдин 2001: 137].

Однако попытки выяснить происхождение и семантику слова қъазақ предпринимаются и в наши дни. Одна из таких попыток была недавно предпринята молодым казахским арабистом К. Кыдырбаевым, который считает, что это слово обозначало «отделившийся со своим имуществом», «отдельно поставивший юрту» и т. п. (каз. яз. - «үйге кірген, үйлі болған, бөлінген»). По его мнению, в оригинале так называемого «Кыпчакско-арабского словаря» арабским эквивалентом кыпчакского слова ққазақ является

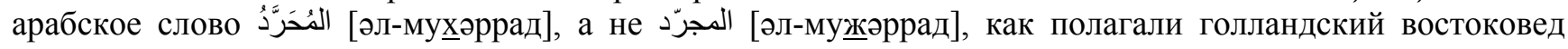
М. Т. Хоутсма и последующие исследователи [Қыдырбаев 2015]. Однако данное мнение не подтверждается материалами исторических источников XV-XVII вв., в которых зафикировано социальное значение термина қ̧азақ..

Помимо трудов казахских ученых, трактовки термина ққзақ содержатся и в работах современных зарубежных исследователей. «Этноним казах имеет общее происхождение со словом казак и образован от тюркского глагола qač- “бежать”, “сбежать”, отсюда qačaq - “сбежавший”, “беженец”, “вольный человек”. Так называли кочевников, неподчиняюшихся закону и ведущих вольный образ жизни, т. е. они были вне государства и его порядков», - считает узбекский арабист Ш. С. Камоллидин [Камоллидин 2018: 50]. Следует отметить, что такая точка зрения на отношение казахов к государству довольно распространена в научной литературе. Поэтому здесь, на наш взгляд, уместно привести слова В.В.Бартольда, который еще в начале XX в. подчеркивал, что «несмотря на свое название, казахи не отвергали ни традиций степной государственности, ни прав потомков Чингиз-хана» [Бартольд 1963: 270]. На то, что у казахов до XIX в. сохранялись правовые нормы Ясы Чингисхана (некоторые из них, возможно, только приписывались ему), указывали многие исследователи казахского права. В частности Я. Гурлянд писал: «...Чингисова "Великая Яса" была важнейшим законодательным уложением киргизов (казахов. - Aвm.) того времени. Киргизские законы очень похожи на древние монгольские уставы...» [Қазақтың ата заңдары 2005: 256]. Эти утверждения исследователей вытекали и из сообщения самих казахов. Например, П. И. Пашино в работе «Туркестанский край в 1866 году. Путевые заметки» указывал, что казахи говорили ему: «...у нас Чингиз-ханова яса, его обычаи» [Путевые заметки 1868: 83].

Современный канадский исследователь Joо-Yup Lee, автор исследования "Qazaqliq, or Ambitious Brigandage, and the Formation of the Qazaqs", считает, что словом qazaq/қазақ обозначалось «политическое бродяжничество», а термин qazaqliq/казаклык означал «обычай политического бродяжничества». Он пишет: «“Қазақ” был политическим бродягой, который покинул свое государство или племя, блуждал в некоторых отдаленных районах, служивщих ему убежищем, и занимался разбоем, чтобы вернуться, или прийти к власти, или, по крайней мере, совершить набег на добычу. По сути, “Қазақ” был амби- 
циозным разбойником» (“A qazaq was a political vagabond who left his state or tribe, wandered in some remote areas that served as a place of refuge, and engaged in brigandage in order to return or rise to power, or at least to raid for booty. In essence, a qazaq was an ambitious brigand") [Lee 2015: 164].

Однако при таком рассмотрении семантики термина قزاق)қазақ непонятно его отличие от тюркского

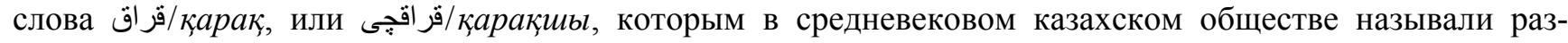
бойников [Юдин 2001: 150]. Например, в послании Тауке-хана к русскому воеводе говорилось: «С каких это пор было, чтобы посланца (илчи) задерживали как разбойника (карақчи)» [Эпистолярное наследие 2014: 87]. Еще А. Н. Самойлович, рассматривая значение слова қазақ, писал: «Сомнительным для классического чагатайского языка является неподтвержденное цитатами значение “разбойник”» [Самойлович 1927: 10]. М. Т. Тынышпаев также отмечал, что «когда хотят сказать по-джагатайски разбойник, никогда это понятие не выражают словом “казак”». Он указывает, что «по-джагатайски разбойник - каракчи» [Тынышпаев 1993: 124].

Согласно мнению А. Н. Самойловича, высказанному еще в 1927 г., слово қ̧азақ̆/казак появилось не ранее XI в. на территории, подвластной кыпчакам, и обозначало социальное состояние человека, отделившегося от своего государства, племени или рода и принужденного вести жизнь искателя приключений [Самойлович 1927: 13]. Позже это его определение было дополнено и расширено Т. И. Султановым, который писал, что первоначально слово қазақ «имело нарицательное значение в смысле свободный, бездомный, скиталец, изгнанник. Не имея, таким образом, ни политического значения, ни этнического содержания, слово казак обозначало всякого вольного человека, отколовшего от своего народа и племени или своего сеньора и принужденного вести жизнь искателя приключений» [Кляшторный, Султанов 1992: 250]. В 90-е гг. ХХ в. Б. Е. Кумеков, специально рассмотревший данный вопрос, пришел к заключению о бытовании в IX-X вв. в обществе кыпчаков Восточного Дешт-и Кыпчака социальных, а в XIXII вв. - этносоциальных группировок под названием қ̧азақ.. «Однако из этого не следует вывода об образовании в предмонгольского время этноса казак, тем более о формировании казахской народности», - резонно отметил исследователь [История Казахстана 1997: 300]. Некоторые современные специалисты считают, что слово қ̧азақ долгое время бытовало в качестве соционима, обозначавшего в тюркском обществе после монгольского времени определенную социальную группу, а также определенный тип социального поведения [Краткий энциклопедический словарь 2014: 207].

Как известно, в исторической литературе до последнего времени доминировало мнение, что основу казаков в России и Украине составили беглые крестьяне. Рассматривая советскую историографию истории казачества, В. В. Грибовский указывает: «Основным источником пополнения казачества были признаны крестьяне, бежавшие от феодального гнета из центральных районов на степную периферию» [Казачество 2018: 25]. Такой способ формирования казачьих общин был характерен для европейской части Евразии. Совершенно другой, на наш взгляд, была природа формирования феномена «казаклык»/казакования в кочевой тюркской среде.

Впервые термин ق̈اقزқазақ зафиксирован в труде XIII в. «Китаб-и Маджмуе-и Тарджуман-и Турки ва ‘Аджами ва Мугали ва Фарси» Халила бин Мухаммада бин Йусуфа ал-Кунави. Именно это сочинение, написанное в 1243 г., исследователи долгое время ошибочно называли «анонимным тюрко-арабским словарем», «арабо-кыпчакским словарем», «кыпчакско-арабским словарем» и датировали 1245 г. В этом труде ал-Кунави приводится следующее толкование интересующего нас слова: «ķazak - холостой, вольный человек, казак; الدجرّ холостяк; отказавшийся от от мирских благ, аскет» [Гаркавец 2019: 576].

Исследуя «Китаб-и Маджму“-и Тарджуман-и Турки ва 'Аджами ва Мугали ва Фарси», А. Н. Гаркавец приходит к выводу, что «термин қазақ указывает на гражданское состояние отдельно взятого человека, индивида - неженатый, не связанный узами брака, семьи (укр. козак//парубок парень, еще не женатый молодой человек, юноша), а в равной степени его общественный статус - одиночка, единоличник, никому не подчиненный, ни от кого не зависящий, вольный, свободный, неподвластный, не связанный общественными обязанностями и повинностями, самостоятельный, сам себе господин» [Гаркавец 2015: 36]. Развивая далее эту мысль, В. В. Грибовский считает, что в труде ал-Кунави, когда объясняется смысл слова қазақ, речь идет о возрастном классе неженатой, «гулящей» мужской молодежи, мужском союзе, действующием вне семейного пространства» [Казачество 2018: 94]. Далее автор пишет, что раннее казачество (казаклык) представляет собой мужской союз, заключающий в себе возрастные классы, выстроенные по рангам, обретаемым на основе инициации [Казачество 2018: 171]. Однако если этот союз разделен на возрастные классы и делится по рангам, то вышеприведенные А. Н. Гаркавцом характеристики общественного статуса қазақ неприемлемы. Если человек состоит в союзе с кем-то, то он не может быть одиночкой и единоличником, он также не может быть полностью свободным, т. к. в таком союзе также обязательно должна существовать внутренняя соподчиненность. 
Это значение слова қุазақ̆/казак как неженатого человека фиксирует и В. В. Радлов, который в «Словаре тюркских наречий» указывает: «kaзаk кіші, kaзak jiгіт неженатый человек, холостяк - ein unverheirather Mensch, Junggeselle» [Радлов 1899: 365].

Следует отметить, что казакование/«казаклык», на наш взгляд, было прежде всего характерно для маргинальных зон. Переход к казакованию вел к изменению всей сущности хозяйства кочевника. Теперь он свою жизнедеятельность обеспечивает не скотоводством, как ранее, а живет за счет охоты и военных набегов. Поэтому, вероятно, правы те исследователи, которые видели основу слова қазақ в тюркском глаголе ққаз- - копать, рыть. «Глагол қ̧азzан-// ққазzан- является, по-видимому, производимым от глагола қ̧аз- "копать” с первичным значением “докапываться”, “добиваться”, “достигать”... Мы полагаем, что слово қ̧аздақ и является первичной формой слова қ̧азақ, т. е. қ̧азақ является в конечном счете производным от корня, общего со словом қ̧аздан-// қ̧азан», — писал, в частности, В. П. Юдин [Юдин 2001: 161]. Соглашаясь с ним, мы также считаем, что исходной формой термина қ̧азақ было қ̧азвақ̆. Этим словом называли молодых людей, перешедших к казакованию и живших не в юртах, в отличие от кыпчаковкочевников, а в домах, которые они сами вырыли, выкопали в лесных и горных массивах. Возможно, что эти юноши могли носить гордое имя қазақ только после прохождения своеобразного обряда посвящения — инициации [Зуев 1998: 49—100; Галиев 1997: 49—50, 65].

Однако простой кочевник не мог в одиночку заниматься казакованием. В аридной зоне Евразии, где население в основном жило за счет скотоводства, «ни один индивид не мог самостоятельно обеспечить выполнение всех минимально необходимых для жизни производительных функций» [Масанов 2011: 378]. Иными словами, простой кочевник не может один выжить в степи. Поэтому такие люди должны объединяться в общины, однако даже так сложно выжить, особенно зимой, в суровых степях Евразии. Так, например, Захир ад-Дин Бабур отмечал: «В ту зиму некоторые из наших воинов не могли больше казачествовать с нами и попросили разрешения уйти в Андиджан» [Бабур 1992: 84]. А ведь этот тимурид и его люди казаковали в Средней Азии, климат которой был более мягким по сравнению с Восточным Дешт-и Кыпчаком.

Однако до второй половины XIV в. переход кочевого населения Дешт-и Кыпчака к «казаклык»/ казакованию, на наш взгляд, был очень редким явлением. Как известно, с XIII в. Дешт-и Кыпчак входил в состав Улуса Джучи и являлся частью империи Чингисхана, в которой действовали правовые нормы Ясы. Одна из норм Ясы устанавливала запрет на свободное перемещение подвластного населения. В «Тарих-и Джахангушай» имеется следующее указание: «А еще яса такая: чтобы никто из тысяч или десятков, к которым он приписан, не смел уходить в другое место или укрываться у других» [Сокровенное сказание 2015: 270]. Плано Карпини (XIII в.) также утверждал, что, согласно монгольским законам, «никто не смеет пребывать в какой-нибудь стране, если император не укажет ему. Сам же он указывает, где пребывать вождям, вожди же указывают места тысячникам, тысячники - сотникам, сотники же десятникам» [Сокровенное сказание 2015: 454].

В. В. Трепавлов отмечает, что в Монгольской империи центральная власть не допускала «самовольных переходов из одного улуса в другой, чтобы не нарушать стройной организации налогооблажения и военной мобилизации» [Казачество 2018: 173]. По его мнению, к первой половине XV в. ситуация изменилась, в это время в Улусе Джучи появляется степная вольница, обозначаемая в тюркском языке словом казак/қазақ.. «Во второй половине XV в. казаки начинают фигурировать в источниках как заметный элемент социальной структуры и как участники политических событий», - пишет исследователь [Казачество 2018: 173-174]. На наш взгляд, это произошло еще раньше, в период «Великой замятни», которая началась в 1359 г. после смерти Бердибек-хана. Ослабление центральной власти и борьба за Сарайский престол привели к тому, что к казакованию перешли представители степной элиты, которые также претендовали на трон, но были менее удачливы, чем их родственники.

В труде «Кара таварих» Утемиша-хаджи указывается, что чингизид Хидыр-хан возглавлял группу «казаков» [Утемиш-хаджи 2017: 52]. Этот хан был убит в 1360 г., т. е. в период «Великой замятни». Согласно Утемиш-хаджи, в 60-е гг. XIV в. некоторые время казаковал другой чингизид - Тохтамыш-хан [Утемиш-хаджи 2017: 55].

В других источниках содержатся сведения о «казаклыке»/казаковании Шибанидов Абу-л-Хайр-хана и его внука Мухаммеда Шейбани-хана, Кучум-хана и др. [Кляшторный, Султанов 1992: 251]

Источники указывают, что такими казахами были и Керей и Жанибек, потомки Урус-хана и будущие основатели Казахского ханства. Так, например, Мирза Мухаммед Хайдар Дуглат писал: «Так как они [Кирай и Джанибек] сперва, бежав и отделившись от своего многочисленного народа, некоторое время пребывали в беспомощности и скитаниях, их прозвали казахами, и прозвище это закрепилось за ними» [МИКХ 1969: 222]. Это же подтверждается сведениями «Тарих-и Кашгар»: «Убегая от Абу-л-хайра, Курай хан с Джанибек ханом ушли в Могулистан. В улусе могулов правил Исанбуга хан, пришло разруше- 
ние ///, этим дали название казахи, по причине того, что одинокие /// (жили), прячась (убегая?) от других, стали называть их казахами» [Миргалеев, Сайфетдинова 2015: 85].

Во второй половине XIV в. казаковали и в бывшем Чагатайском улусе. В связи с событиями 1376 г. в тимуридской историографии встречается выражение «Казакская тысяча» - «хазаре-йи қазақ» [Йазди 2008: 82]. В «Тарих-и Рашиди» Мирза Мухаммед Хайдара сообщается о казаковании ТоглукТимуридов - Уайс-хана и Саид-хана. Мирза Мухаммед Хайдар о будущем хане Могулистане Уайсхане пишет так: «После смерти отца он находился при дяде Шир Мухаммад хане, а когда достиг совершеннолетия, то стал тяготиться этим, ушел от него и начал появляться в разных местах по обычаю казакования. В улусе моголов каждый юноша, считающий себя бахадуром и претендующий на это, шел к нему» [Мухаммед Хайдар 1999: 91].

Известно также, что казаковали тимуриды Султан Хусеин и Захир ад-Дин Бабур [Кляшторный, Султанов 1992: 251].

Таким образом, в этот период «казаклык»/казакование становится методом политической борьбы. Термином қазақ стали в первую очередь обозначать представителей высшей знати, которые в период неудачной борьбы за престол временно занялись казакованием на окраинах степей. И не зря Захир адДин Бабур определяет время своего казакования как время «казачества и безвластия» [Бабур 1992: 152].

Исследователям хорошо известно и часто цитируется объяснение, данное термину قزاق/қазақ аштарханидским ученым-историком Махмудом ибн Эмир Вали, который в своем труде «Бахр ал-асрар» пишет: «Так как в [самом] начале [после] прибытия в Могулистан они проводили время в набегах на калмаков и киргизов и грабежах их и на окраинах областей занимались разбоем, к этому народу (тайифа) пристало имя казак» [МИКХ 1969: 353]. Вместе с тем нужно понимать, что слова Махмуда ибн Эмира Вали отражают взгляд представителя «оседлого» мира (жителя города Балха), плохо знакомого с особенностями жизни, традициями и обычаями кочевников. Также следует учитывать тенденциозность историка, служившего у политических противников казахов - Аштарханидов.

Иначе характеризуются казахи в произведениях средневековых историков, предки которых принадлежали к кочевой среде и хорошо знали ее обычаи и традиции. Например, тимурид Захир ад-Дин Бабур, который сам некоторое время казаковал и был казаком, отзывается о казаках как об отважных «молодцахказаках» (قزاق ييكيت لار) [Бабур 1992: 67; Бабур-намэ 1857: 88]. В своем труде он говорит о Толун-ходжемогуле как об одном из мужественных, выдающихся и казахских джигитов (مردانه و سرامد و قزاق ييكيتلاريدين الايدى). Далее он пишет еще раз: «Удивительно мужественным, казахом был йигит» (عجب مردانه و قزاق ييكيت ايدى ) [Бабур-намэ 1857: 65]. Несколько иначе переведен этот отрывок на русский язык у М. А. Салье: «Тулун Ходжа из [племени] Барин был один из самых смелых, храбрых и удалых йигитов... Удивительно смелый и удалой был йигит» [Бабур 1992: 557]. Как видим М. А. Салье слово құазақ переводит как «удалой». Отметим также, что и иранский историк XVI в. Гияс ад-Дин Хондемир называет подчиненных Тулунходжа-могула «отважные казахские люди» (мардум-и казак-и дил-авар (مردم قزاق دلاور) [Тарих-и Хабиб ассийар 2001-2002: 231].

Мирза Мухаммед Хайдар рассматривает казакование как некий обычай и пишет несколько раз «по казакскому обычаю» (به رسم قز اقى) [Тарих-и Рашиди 2004: 87, 91]. Какой это был обычай, позволяет понять следующее его сообщение: «Среди племен мира у племени моголов есть такой обычай: их смелые юноши долгое время живут в одиночестве в пустыне, в горах или лесах, которые удалены от людей на один-два месяца пути. Одеждой и пищей им служат шкура и мясо газели, и это они считают смелостью и мужеством, и это, в самом деле, очень трудное и опасное дело» [Мухаммед Хайдар 1999: 218]. Хотя автор говорит, что это обычай могулов, вероятно, этот обычай был характерен и для политической элиты Восточного Дешт-и Кыпчака.

Естественно, элита казаковала не в одиночестве. В сочинении «Таварих-и гузида-йи нусрат-наме» приводятся имена людей, казаковавших вместе с Шибанидом Абу-л-Хайр-ханом: Кирни-Таринчакбахадур, Илин-ходжа, Суфра-ходжа, Йакуб-ходжа, Йусуф-ходжа, Кара-Камыш-Бахрам-ходжа, Йункачук-Толун-ходжа, «из минбеги тумана» Кылыч-бай-бахадур, Бурджи-Кара-Даулат-ходжа-бахадур, Йабагу, Йахши-ходжа, Инка-ходжа, Йумадук, Дарвиш-бахадур, Шайх-Мухаммад-бахадур, Кудагай, Усманбахадур, Инак-Йаглы-ходжа, Уруш-бахадур [МИКХ 1969: 16-17]. В «Шейбани-наме» Камал ад-Дина Бинаи также приводится имена казаков-сподвижников Абу-л-Хайр-хана: Йахши-бек-бахадур, КутлукБука-бахадур, Йакуб, Кара-Кирай, Шайх-Суфи-бек, Али-хаджи, Даулат-ходжа, Кара-Усман, Суфи-бек, Акча-Урус, Ходжа-Лак-бахадур, Йумадук-бахадур, Сабур-Шайх-бахадур, Йадгар-бахадур. Камал адДин Бинаи еще упоминает следующие имена казаков Абу-л-Хайр-хана: Йакуб-ходжа, Йусуф-ходжа, Кырк-Беш-Бахрам-ходжа, Тункачук-и-Тулун-ходжа, Кылыч-бахадур, Йоджи-Кара, Даулат-ходжа, Йапагу, Бахти-ходжа, Инка-ходжа, Йумадук, Дарвиш-бахадур, Шайх-Мухаммад, Караугай, Усман-бахадур, 
Инак-Йаглы-ходжа, Урус-бахадур [МИКХ 1969: 96-97]. Как видим, эти люди были также представителями степной кочевой элиты - бахадуры, ходжи, беки и минбеги.

В «Таварих-и гузида-йи нусрат-наме» эти люди, сопровождавшие Шибанида Абу-л-Хайр-хана во время казакования, предстают батырами (бахадурами), которые «рубили саблями», «проявили усердие», «стали причиной его могущества» [МИКХ 1969: 16-17]. Схожую характеристику дает им автор «Шейбани-наме» Камал ад-Дина Бинаи, когда говорит о них: «Общество (“джамаат”) эмиров, которые во время казачества [Абу-л-Хайра] жертвовали собой, стали причиной могущества хана... Эти сподвижники... во время казачества [Абу-л-Хайр-хана] проявили верность и завоевали страны» [МИКХ 1969: 96]. Еще в одном месте он пишет: «Другое общество из казаков, [которые] во времена казачества также самоотверженно сражались» [МИКХ 1969: 97].

Даже Махмуд ибн Эмир Вали, тенденциозность которого мы отмечали выше, отзывается о спутниках-казаках Керея и Жанибека как о людях «достойных признания» [МИКХ 1969: 353].

В XVI в. историк Фазлаллах ибн Рузбихан Исфахани значение термина қазақ перенес (не без причины) на все население Казахского ханства, когда писал: «Второе племя — казахи, которые славны во всем мире силою и неустрашимостью (قوة و بأس) (Ибн Рузбихан 1976: 62; Михман-наме-йи Бухара 1976: 41]. Так характеризовали казахов и в Западной Европе. В 1705 г. голландский исследователь Николаас Витсен в своей книге «Северная и Восточная Тартария» писал: «Откуда возникло название “козаки”, что оно обозначает, - мне не известно, однако я предполагаю, что это имя им было дано, потому что они воины и очень храбрые» [История Казахстана 2006: 150]. В другом месте он отмечает, что казахи «искусные всадники, великолепные воины» [История Казахстана 2006: 87].

Ч. Ч. Валиханов совершенно справедливо отмечал: «...имя казак (قز)... в то время имело значение довольно почтенное и означало возвышенность духа, здравость - соответствовало европейскому рыцарству» [Валиханов 1985: 152]. В. П. Юдин также обращал внимание, что слово «казак» у украинских казаков было синонимом слова «рыцарь», а у донских казаков оно было синонимом слова «мущщин» (мужчина). Он же отмечал, что в тюркских языках за словом казак закрепились значения «одинокий», «неимущий», «мужчина», «муж», «удалец», «герой» и т. д. Исследователь писал: «В глазах простых смертных казак был олицетворением мужества, отваги, стойкости, неприхотливости» [Юдин 2001: $149-150]$.

Тем самым «казаклык»/казакование было, с одной стороны, методом политической борьбы, с другой - обычаем смелости и мужества. Этим объясняется свидетельство исследователей ХІХ в. (Ч. Ч. Валиханов, Г. М. Броневский) о том, что казахи гордились своим этническим наименованием [Валиханов 1985: 152; Записки 1830: 170].

Таким образом, подытоживая вышеприведенные материалы, мы можем предположить следующие этапы развития термина қ̧азақ в Восточном Дешт-и Кыпчаке XIII-XVI вв.

Первый этаn: XIII в. - вторая половина XIV в. Словом қ̧азақ на этом этапе называли неженатых, молодых людей, которые на время рвали связи со своим родственниками и уходили в отдаленные места, где проходили своеобразную школу выживания. Причем уход этот был добровольным, и никто не был «принужден вести жизнь искателя приключений». Эти юноши, возможно, становились казахами через особый обряд инициации.

Тем самым, слово қазақ в это время не несло никакого негативного значения и не было связано с понятиями «беглец», «сбежавший» и др. Однако количество людей, перешедших к казакованию и ставших «казахами», в тот период было очень незначительным.

Термин «казаклык»/казакование обозначал в тот период обычай «смелости и мужества».

Bmopoŭ эman: со второй половины XIV в. по 1465 гг. На этом этапе в Восточном Дешт-и Кыпчаке (и в бывшем Чагатайском улусе) словом қ̧азақ в первую очередь называли чингизидов, которые в условиях политической борьбы были вынуждены оставить свои исконные владения и заняться казакованием. Ушедшие в Могулистан джучиды Керей и Жанибек были одними из таких представителей степной элиты, боровшихся за престол и вынужденно оставивших свой йурт (юрт).

Термин «казаклык»/казакование обозначал распространенный в среде чингизидов метод политической борьбы, а также, как и ранее, обычай «смелости и мужества».

Tpeтий этan: с 1465 г. до конца XV в. С созданием Керей-ханом и Жанибек-ханом своего государства в Жетысу словом құазақ соседи стали называть подвластное им население. Так термин қ̧азақ приобрел значение политонима.

Согласно «Тарих-и Рашиди» чагатаидского историка Мирза Мухаммед Хайдара дуглата, людей, признавших власть ханов Керея и Жанибека, «стали называть “узбек-казаками”» [Мухаммед Хайдар 1999: 108]. Далее историк применяет это наименование для обозначения подданных казахских ханов Керея и Жанибека и их первых преемников. 
Следует отметить, что в исторических источниках шибанидского круга термин «узбек-казах» не встречается. В написанных в первой половине XVI в. исторических трудах «Шейбани-наме» Камал адДина Бинаи, «Зубдат ал-асар» Абдаллаха Балхи, «Бадаи ал-вакаи» Зайн ад-Дина Васифи подвластное ханам Керею и Жанибеку и их потомкам население названо «казахами» [МИКХ 1969: 107, 132 — 133, 177]. Население Казахского ханства за редким исключением в мусульманских сочинениях этого периода именуется «казахи».

Термин «узбеки-казахи» фигурирует кроме «Тарих-и Рашиди» Мирза Мухаммед Хайдара дуглата в «Бахр ал-асрар» аштарханидского историка Махмуда ибн Вали. Однако из текста видно, что он использует этот термин, когда повторяет сведения «Тарих-и Рашиди» [МИКХ 1969: 329, 353], а в остальных случах он пишет «казахи» [МИКХ 1969: 329-335, 337, 365-366].

В западных исторических источниках термин «узбеки-казахи» также не фиксируется. В русских архивных документах начиная с 1503 г. население Восточного Дешт-и Кыпчака именуется «казаки» [История Казахстана 2005a: 46, 48, 61, 63; Исин 2004: 53], а их государство - «Казацкая (вар. Казатцкая, Кайсацкая, Киргиз-казацкое, Киргис-кайсацкая, Казачья) Орда» [ПДРВ 1791: 244; Сборник 1895: 668; История Казахстана 2005a: 57, 58, 63, 196, 340, 395; История Казахстана 2005б: 270-271]. В Европе тогда жители казахских степей были известны как «Cassaki». В 1517 г. поляк М. Меховский, перечисляя восточные государства - «татарские орды», писал: «Добавляют еще и пятую, не имеющую императора, и называют ее казакской» (Kazacka) [Меховский 1936: 63, 144]. Австрийский дипломат С. Герберштейн, посетивший Москву в первой половине XVI в., в числе «различных орд татаров» упоминает и казахов («Cassaki») [История Казахстана 1997: 29]. О борьбе казахов с Ташкентом писал в 1558 г. английский путешественник и купец А. Дженкинсон [История Узбекистана 1988: 29-30] В европейских картах, составленных чуть позже - в 1560-1604 гг., отмечен топоним Cassackia/Cossackia как название страны [Туран 2008: 171, 176, 181, 182].

Надо полагать, что термин «узбеки-казахи» в самой среде населения Казахского ханства не использовался, т. е. он не был их самоназванием. Возможно, данный термин применяли жители Могулистана, которые таким образом отличали их от узбеков, подвластных Шибанидам. Однако и это название в их среде использовалось недолго. Как было уже отмечено М. К. Козыбаевым и К. А. Пищулиной, «в краткий срок, в жизни буквально одного-двух поколений термин “казах" вытеснил термин “узбеки-казахи””. $\mathrm{B}$ «Тарих-и Рашиди» Мирза Мухаммед Хайдар уже при описании событий периода правлений ханов Бурундука и Касыма применяет чаще термин «казахи» [Мухаммед Хайдар 1999: 13].

Очень интересно замечание 3. А. Джандосовой и И. В. Ерофеевой, что «впервые за всю историю Дашт-и Кипчака созданная казаками “вольница" не распалась, а окрепла в своей обособленности. Через полвека социальное значение термина (для этой общности) полностью нивелировалось, а этническое начало актуализировалось с помощью политического движка» [Краткий энциклопедический словарь 2014: 209]. Созданная ханами Кереем и Жанибеком общность казахов не просто окрепла в своей обособленности, она создала впервые в истории свою политическую организацию - Казахское ханство. В свою очередь, Казахское ханство в дальнейшем обеспечило сложение этой общности в особый этнический коллектив - казахский народ.

Четвертый этап: с конца XV в. до середины XVI в. В это время происходит этнополитическое разделение населения Восточного Дешт-и Кыпчака, именуемого еще Узбекским улусом. Раньше всех к концу XV в. - обосабливается от других узбекских племен население Мангытского юрта и приобретает новое этнополитическое название «ногаи» («ногайлы») [Трепавлов 2002: 4]. На рубеже XV и XVI вв. с перекочевкой из степи двух больших групп кочевых узбекских племен во главе с Шибанидами на территорию Средней Азии происходит еще одно разделение кочевого населения Восточного Дешт-и Кыпчака.

В междуречье Сырдарьи и Амударьи начинает формироваться новая этнополитическая общность, которая в исторических источниках именуется как «узбеки-шибаны» или «узбеки-шибаниты». Первая часть данного этнополитонима показывала их этническое происхождение, а вторая - политическую принадлежность. Однако это наименование «довольно быстро вышло из употребления» [Трепавлов 2019: $351-371]$.

Наименование «казахи» распространяется на население, оставшееся на территории Восточного Дешт-и Кыпчака и вошедшее в состав Казахского ханства. Термин қ̧азақ приобретает значение этнополитонима.

Появляются уже три этнополитические общности, происхождение которых связано с «Узбекским улусом». Именно этот период фиксирует автор «Михман-наме-йи Бухара» Фазлаллах ибн Рузбихан Исфахани, который пишет: «Три племени относят к узбекам, кои суть славнейшие во владениях Чингизхана. Ныне одно [из них] - шибаниты и его ханское величество после ряда предков был и есть их повелитель. Второе племя - казахи, которые славны во всем мире силою и неустрашимостью, и третье пле- 
мя - мангыты, а [из] них цари астраханские» [Ибн Рузбихан 1976: 62; Ускенбай 2012: 183-187]. Однако эти три группы по языку, антропологическим и другим социально-культурным характеристикам не отличались друг от друга [История Казахстана 1997: 290, 291, 317].

В «Тарих-и Рашиди» Мирза Мухаммед Хайдара дуглата встречается интересное утверждение о том, что в 30-е гг. XVI в. казахи совершенно исчезли. В одном месте он пишет: «После 940 года его (казахского хана Буйдаша. - Авт.) также не стало и казахов совершенно не осталось» [Мухаммед Хайдар 1999: 108; Тарих-и Рашиди 2004: 109]. В другом месте Мирза Мухаммед Хайдар указывает: «...в истории казахов было тысяча тысяч человек, а в сорок четвертом из этого числа людей не осталось на земле и следа» [Мухаммед Хайдар 1999: 324; Тарих-и Рашиди 2004: 405]. Эти сведения автора «Тарих-и Рашиди» исследователи интерпретируют по-разному. На наш же взгляд, здесь отражено понимание термина қъазақ Мирза Мухаммед Хайдаром. Он видит в этом термине политоним и связывает существование казахов только с их политическим объединением - Казахским ханством. Уже находясь в Кашмире он, вероятно, получил известие о том, что государство казахов распалось. По этой причине автор «Тарих-и Рашиди» воспринял это недостоверное известие как свидетельство об исчезновении и самих казахов. В ходе наступившей после смерти Касым-хана междоусобицы и неудачной борьбы с внешними врагами Казахское ханство в 30-40-е гг. XVI в. (до начала правления Хакк-Назар-хана) действительно перестало играть существенную политическую роль в регионе и потеряло часть своих земель и населения. Однако, даже оказавшись на некоторое время под властью соседних государств, бывшие подданые ханов Керея и Жанибека и их потомков продолжали называть себя казахами. Казахское ханство, несмотря на все катаклизмы, не исчезло с политической карты мира: в 50-е гг. XVI в. оно, окрепнув в период правления Хакк-Назар-хана, вновь объединило это население. На наш взгляд, это свидетельствует о том, что в этот период термин қ̧азақ был не политонимом, а уже стал этнополитонимом.

И последний, пятый этаn: с середины XVI в. и до наших дней. Во второй половине XVI в. родоплеменной состав населения Казахского ханства более или менее стабилизировался (хотя незначительные переходы родоплеменных групп наблюдались и позже). Это позволило правившему тогда Хакк-Назархану провести политическую и социальную реформу и создать новую систему управления ханством. На смену улусной системе организации казахского общества приходит жузовая система [Султанов 1982: 84-85], хотя название «улус» продолжает применяться. В рамках новой жузовой системы начинает формироваться представление о генеалогическом родстве всех казахов. Возникают генеалогические легенды о мифическом родоначальнике казахского народа, которого, по одним вариантам шеджере (шежіре), называют құазақ, по другим - «Алаша-хан». [Мәшһүр Жүсіп Көпейұлы 2006: 42, 45; Галиев 1997: 138-141; Қайдар 2008: 407; Краткий энциклопедический словарь 2014: 214; Эпистолярное наследие 2014: 405]. Три сына Алаша-хана, согласно шеджере, были прародителями трех жузов казахов. «Все три орды, составляющие союз Казах (так называют себя киргизы), считают своим родоначальником некоего Алача...», - писал Ч. Ч. Валиханов [Валиханов 1985: 308].

С именем Алаша-хана (Алача-хана) «народная память связывает эпоху этнической консолидации казахских родов и племен, образование триальной социально-территориальной структуры кочевого населения Казахского ханства в форме Старшего, Среднего и Младшего жузов и укрепления казахской государственности во внутренней части евразийского континента» [Ерофеева 2016: 257]. Еще М. Т. Тынышпаевым высказывалось мнение, что прообразом легендарного Алаша-хана был Хакк-Назар-хан, сын Касым-хана [Тынышпаев 1993: 148-149]. Эту точку зрения разделяют и некоторые современные исследователи. Так, И. В. Ерофеевой была предпринята попытка показать тождество Хакк-Назар-хана и Алашахана. Рассматривая разные варианты преданий об Алаше-хане, автор приходит к выводу, что «Хаккназар-хан, как видно из учтенных фольклорных материалов, вошел в устную историю своего народа исключительно под лакабом Алаша-хан» [Ерофеева 2016: 282].

Возможно, со временем лакаб Алаша-хан в исторической памяти казахов трансформировался в «Алаш», а выражения Алаша-хан ұлыстары (Улусы Алаша-хана), Алаша-хан жұрты (Страна Алаша) в Алаш ұлыстары («Алаш(ц)ские улусы») и Алаш жұрты («Алацкий йурт/ владения»), зафиксированные в XVIII в. в письмах Абу-л-Хайр-хана и Абылай-хана [Эпистолярное наследие 2014: 96, 334; Краткий энциклопедический словарь 2014: 211]. На существование в народной памяти связи слов Алаши/ Алаша//Aлашы с исторической личностью обращает внимание А. Кайдар. Эта личность, по фольклорным материалам, была ханом казахов или всех тюрко-монгольских племен. Исследователь также указывает, что по некоторым историческим материалам слово «Алаш» до превращения его в этноним было ураном (боевым кличем) казахов [Қайдар 2008: 407-409, 415].

Так постепенно термин Алаш стал отражать, как и термин қ̧азақ, самоидентификацию населения Казахского ханства, Казахстана. А термин қазақ для соседних народов приобрел этнический смысл и стал употребляться как этноним для обозначения населения Казахского ханства, Казахстана, хотя его перво- 
начальное, социальное значение продолжали использовать для обозначения вольных общин европейских степей.

Однако казахи еще долго помнили свое узбекское происхождение. Для Кадыргали-бека Косымулы Жалаири, покинувшего, вероятно, казахские степи еще в период правления Хакк-Назар-хана и не заставшего его реформы, эта территория в начале XVII в. все еще была «Узбекия» (اوزبيك يا), хотя он знает об «Алаш мыңы» (الاج منكى), который насчитывает 300 тысяч человек [Березин 1854: 164, 171]. Даже в XIX в. некоторые казахи говорили русским исследователям: «Предки мои, начало мое - узбеки», «мы все узбеки; начиная от Оренбурга, куда ни поедешь - все будут узбеки» [Кляшторный, Султанов 2000: 239; Путевые заметки 1868: 83].

\section{Литература}

Асфендияров 1935 - Асфендиаров С. Д. История Казахстана (с древнейших времен). Т. 1. Алма-Ата, 1935. \{Asfendiarov S. D. History of Kazakhstan (from ancient times). Vol. 1. Alma-Ata, 1935.\}

Бабур 1992 - Захир ад-дин Бабур. Бабур-наме. Ташкент, 1992. \{Zahir ad-din Babur. Babur-name (Book of Babur). Tashkent, 1992.\}

Бабур-намэ 1857 - Бабур-намэ. Казань, 1857. \{Babur-name (Book of Babur). Kazan, 1857.\}

Бартольд 1963 - Бартольд В. В. Сочинения. Т. ІІ. Ч. 1. Москва, 1963. \{Bartold V. V. Writings. Vol. 2. Part. 1. Moscow, 1963.\}

Березин 1854 - Березин И. Библиотека восточных историков. Сборник летописей. Татарский текст с русским предисловием. Т. II. Ч. І. Казань, 1854. \{Berezin I. Library of oriental historians. Compendium of chronicles. Tatar text with Russian preface. Vol. II. Part. I. Kazan, 1854.\}

Валиханов 1985 - Валиханов Ч. Ч. Собрание сочинений в пяти томах. Т. II. Алма-Ата, 1985. \{Valikhanov Ch. Ch. Collected works in 5 volumes. Vol. II. Alma-Ata, 1985.\}

Галиев 1997 - Галиев A. A. Традиционное мировоззрение казахов. Алматы, 1997. \{Galiev A. A. Traditional worldview of the Kazakhs. Almaty, 1997.\}

Гаркавец 2015 - Гаркавец A. H. Codex Cumanicus. Полное издание в 4 томах. Алматы, 2015. \{Garkavets A. N. Codex Cumanicus. Full edition in 4 volumes. Almaty, 2015.\}

Гаркавец 2019 - Гаркавеи А. Н. Китаб-и Маджму'-и Тарджуман-и Турки ва 'Аджами ва Мугали ва Фарси. «Сводная книга переводчика...» Халила бин Мухаммада бин Йусуфа ал-Кунави / При участии О. О. Туякбаева. Алматы, 2019. \{Garkavets A. N. Kitab-i Majmu-i Tarjuman-i Turki wa ‘Ajami wa Mugali wa Farsi. «Translator's Consolidated Book...» of Khalil bin Muhammad bin Yusuf al-Kunawi / With the participation of O. O. Tuyakbaev. Almaty, 2019.\}

Ерофеева 2016 - Ерофеева И. В. Знаковый персонаж казахских преданий Алаша-хан: историческая личность и миф // Тюркологический сборник. 2013-2014. Памяти С. Г. Кляшторного. М., 2016. С. 256-292. \{Erofeeva I. V. Alasha-khan, a crucial character in Kazakh folklore: The historical figure vs. the myth // Turcologica. 2013-2014. In memory of S. G. Klyashtornyi. Moscow, 2016. P. 256-292.\}

Записки 1830 - Записки генерал-майора Броневского о киргиз-кайсаках Средней Орды / Отечественные записки, издаваемые Павлом Свиньиным. № 120. Ч. 42. СПб., 1830. \{Notes by major general Bronevsky on the Kirghiz Kaisaks of the Middle Horde / Domestic notes published by Pavel Svinin. No. 120. Part 42. St. Petersburg, 1830.\}

Зуев 1998 - Зуев Ю. А. О формах этносоциальной организации кочевых народов Центральной Азии в древности и средневековье: Пестрая Орда, Сотня (сравнительно-типологическое исследование) // Военное искусство кочевников Центральной Азии и Казахстана (эпоха древности и средневековье) Сб. ст. Алматы, 1998. С. 49-100. \{Zuev Yu. A. On the forms of the ethnosocial organization of the nomadic peoples of Central Asia in antiquity and the Middle Ages: A Motley Horde, a Hundred (comparative typological research) // Military art of the nomads of Central Asia and Kazakhstan (the epoch of antiquity and the Middle Ages). Collection of Articles. Almaty, 1998. P. 49-100.\}

Ибн Рузбихан 1976 - Фазлаллах ибн Рузбихан Исфахани. Михман-наме-йи Бухара (Записки бухарского гостя). Перевод, предисловие и примечания Р. П. Джалиловой. Под редакцией А. К. Арендса. М., 1976. \{Fazlallah ibn Ruzbihan Isfahani. Mihman-name-ii Buhara. Notes of the Bukhara Guest. R. P. Dzhalilova (trans.), A. K. Arends (ed.). Moscow, 1976.\}

Ибрагимов 1960 - Ибрагимов С. К. Еще раз о термине «казах» // Новые материалы по древней и средневековой истори Казахстана (Труды Института истории, археологии и этнографии КазССР. Т. 8). Алма-Ата, 1960. C. 66-71. \{Ibragimov S. K. Once more on the term "Kazakh" // New materials on ancient and medieval history of Kazakhstan (Proceedings of Institute of History, Archaeology and Ethnography of Academy of Science of Kazakh SSR. Vol. 8). Alma-Ata, 1960. P. 66-71.\}

Исин $2004-$ Исин А. И. Казахское ханство и Ногайская Орда во второй половине XV—XVI в. Алматы, 2004. $\left\{I \sin A\right.$. I. Kazakh Khanate and Nogai Horde in the $2^{\text {nd }}$ half of the $15^{\text {th }}-16^{\text {th }}$ centuries. Almaty, 2004.\} 
История Казахстана 1997 - История Казахстана (с древнейших времен до наших дней). В 5 томах. Т. 2. Алматы, 1997. \{History of Kazakhstan (from ancient times to the present day). In 5 volumes. Vol. 2. Almaty, 1997.\}

История Казахстана 2005a - История Казахстана в русских источниках. Т. I. Посольские материалы Русского государства (XVI-XVII вв.) / Составление, транскрипция скорописи, специальное редактирование текстов, вступительная статья, комментарии, составление словников указателей А. Исина. Алматы, 2005. \{History of Kazakhstan in Russian sources. Vol. 1. Embassy Materials of the Russian state $\left(16^{\text {th }}-17^{\text {th }}\right.$ centuries $) /$ Compilation, transcription of cursive writing, special editing of texts, introductory article, comments, compilation of vocabulary lists by $A$. Isin. Almaty, 2005.\}

История Казахстана 20056 - История Казахстана в русских источниках. Т. 2. Русские летописи и официальные материалы XVI - первой трети XVIII в. о народах Казахстана / Составление, транскрипция, комментарии, вступительная статья И. В. Ерофеевой. Алматы, 2005. \{History of Kazakhstan in Russian sources. Vol. 2. Russian chronicles and official materials from the $16^{\text {th }}$ to the $1^{\text {st }}$ third of the $18^{\text {th }}$ century about the peoples of Kazakhstan / Compilation, transcription, comments, special editing of texts by I. V. Erofeeva. Almaty, 2005.\}

История Казахстана 2006 - История Казахстана в западных источниках XII-XX в. Т. 6. Немецкие исследователи в Казахстане. Ч. 2. Пер. с ранненовоголл. А. П. Евдокимова. Пер. с нем. Л. И. Быковской / Сост. И. В. Ерофеева. Алматы, 2006. \{History of Kazakhstan in Western sources of $12^{\text {th }}-20^{\text {th }}$ centuries. Vol. 6. German experts in Kazakhstan. Part 2. Translation from Early Modern Dutch by A. P. Evdokimov. Translation from German by L. I. Bykovskaya / Comp. I. V. Erofeeva. Almaty, 2006.\}

История Узбекистана 1988 - История Узбекистана в источниках. Известия путешественников, географов и ученых XV - первой половины XIX в. Ташкент, 1988. \{History of Uzbekistan in sources. News of travelers, geographers and scientists of the $15^{\text {th }}-1^{\text {st }}$ half of the $19^{\text {th }}$ century. Tashkent, 1988.

Йазди 2008 - Йазди Шараф ад-Дин Али. Зафар-наме. Перев. со староузб., предисловие, комментарии, указатели и карта А. Ахмедова. Ташкент, 2008. \{Yazdi Sharaf ad-Din Ali. Zafar-name. Translated from Old Uzbek, preface, comments, pointers and map by A. Akhmedov. Tashkent, 2008.\}

Казачество 2018 - Казачество в тюркском и славянском мирах: колл. монография / Отв. ред. В. В. Грибовский, В. В. Трепавлов; Институт археологии им. А. Х. Халикова АН РТ. Казань, 2018. \{Cossacks in the Turkic and Slavic worlds: coll. monograph / Ed. V. V. Gribovsky, V. V. Trepavlov; Institute of Archeology named after A. Kh. Khalikov of the Academy of Sciences of the Republic of Tatarstan. Kazan, 2018.\}

Камолиддин 2018 - Камолиддин Ш. С. Современные концепции в историографии истории Центральной Азии. Ташкент, 2018. \{Kamoliddin Sh. S. Modern concepts in the historiography of the history of Central Asia. Tashkent, 2018.\}

Кляшторный, Султанов 1992 - Кляшторный С. Г., Султанов Т. И. Казахстан. Летопись трех тысячелетий. Алма-Аты, 1992. \{Klyashtornyi S. G., Sultanov T. I. Chronicle of three thousand years. Alma-Aty, 1992.\}

Кляшторный, Султанов 2000 - Клямторный С. Г., Султанов Т. И. Государства и народы Евразийских степей. Древность и средневековье. СПб., 2000. \{Klyashtornyi S. G., Sultanov T. I. States and peoples of the Eurasian steppes. Ancient times and Middle Ages. St. Petersburg, 2000.\}

Краткий энциклопедический словарь 2014 - Краткий энциклопедический словарь исторических топонимов Казахстана / Сост. И. В. Ерофеева. Алматы, 2014. \{Brief encyclopedic dictionary of historical toponyms of Kazakhstan / Comp. I. V. Erofeeva. Almaty, 2014.\}

Кумеков 1997 - Кумеков Б. Е. Историография вопроса о термине құзақ // Материалы Международной научнотеоретической конференции, посвященной известному ученому-историку Мухаммед Хайдар Дулати (1499-1551). Тараз, 1997. C. 32-40. \{Kumekov B. E. Historiography of the issue of the term "Kazakh" // Materials of the International scientific-theoretical conference dedicated to the famous scientist-historian Mohammed Khaidar Dulati (1499-1551). Taraz, 1997. Р. 32-40.\}

Қазақтың ата заңдары 2005 - Қазақтың ата заңдары: Құжаттар, деректі және зерттеулер: 10 томдық. Т. 4. = Древний мир права казахов. Материалы, документы и исследования: 10-томник. Т. 4. Алматы, 2005. \{The ancient world of Kazakh law. Materials, documents and research: 10-volume. Vol. 4. Almaty, 2005.\}

Қайдар 2008 - Қайдар Ә. Қазақ қандай халық? Алматы, 2008. \{Kaidar A. What kind of people are Kazakhs? Almaty, 2008.\}

Қыдырбаев 2015 - Қыдырбаев Қ. «Қазақ» сөзінің мағынасы қандай? (1245 жылы жарық көрген қыпшақ-араб сөздігінің қолжазбасы негізінде) // Қазақ газеттері. 13 ақпан 2015 / http://kazgazeta.kz/24420 (Дата обращения: 1.10.2021) \{Kydyrbayev K. What does the word "Kazakh" mean? (Based on the manuscript of the Kypchak-Arabic dictionary of 1245) // Kazakh newspapers. February 13, 2015. http://kazgazeta.kz/24420 (accessed on: 1.10.2021).\}

Масанов 2011 - Масанов Н. Э. Кочевая цивилизация казахов: основы жизнедеятельности номадного общества. Изд. 2-е, доп. Алматы, 2011. \{Masanov N. E. The nomadic civilization of the Kazakhs: the foundations of a nomadic society. $2^{\text {nd }}$ edition, with suppl. Almaty, 2011.\}

Мәшһүр Жүсіп Көпейұлы 2006 - Мәиһүр Жүсіп Көпейұлы. Шығармалары. 8 том. Қазақ тарихы. Павлодар, 2006. \{Mashhur Jusip Kopeyuly. Writings. Vol. 8. History of Kazakhs. Pavlodar, 2006.\} 
Меховский 1936 - Меховский М. Трактат о двух Сарматиях. Введ., пер. и комм. С. А. Аннинского. МоскваЛенинград, 1936. \{Miechowski M. Treatise on the two Sarmatias. Introduction, translation and commentary by S. A. Anninsky. Moscow-Leningrad, 1936.\}

МИКХ 1969 - Материалы по истории Казахских ханств XV-XVIII вв. (извлечения из персидских и тюркских сочинений) / Сост. С. К. Ибрагимов, Н. Н. Мингулов, К. А. Пищулина, В. П. Юдин. Алма-Ата, 1969. \{Materials on the history of the Kazakh khanates of the $15^{\text {th }}-18^{\text {th }}$ centuries (extracts from Persian and Turkic writings) $/$ Comp. S. K. Ibragimov, N. N. Mingulov, K. A. Pishchulina, V. P. Yudin. Alma-Ata, 1969.\}

Миргалеев, Сайфетдинова 2015 - Миргалеев И. М., Сайфетдинова Э. Г. Сведения «Тарих-и Кашгар» о Золотой Орде // Золотоордынское обозрение. 2015, 2. С. 81-87. \{Mirgaleev I. M., Sayfetdinova E. G. Information of "Tarikh-i Kashgar" on the Golden Horde // Zolotoordynskoe obozrenie = Golden Horde Review. 2015, 2. P. 81—87.\}

Михман-наме-йи Бухара 1976 - Михман-наме-йи Бухара (Тарих-и падешахи Мухаммед Шейбани). Бе талиф-и Фазлаллах ибн Рузбихан Хунджи. Чап-е дуввом. Техран, 2535 шахшахи (1976). \{Notes of the Bukhara guest (The history of Padashah Muhammad Sheybani). Writer - Fazlallah ibn Ruzbihan Isfahan Khunji. $2^{\text {nd }}$ edition. Teheran, 2535 (1976).\}

Мухаммед Хайдар 1999 - Мухаммед Хайдар Дулати. Тарих-и Рашиди. Перевод с персидского языка А. Урунбаева, Р. П. Джалиловой, Л. М. Епифановой. 2-е издание, дополненное. Алматы, 1999. \{Muhammed Haidar Dulati. Tarih-i Rashidi. $2^{\text {nd }}$ edition with suppl. A. Urunbaev, R. P. Dzhalilova, L. M. Epifanova (trans.). Almaty, 1999.\}

ПДРВ 1791 - Продолжение древней российской вивлиофики. Ч. VII. СПб., 1791. \{Continuation of the ancient Russian library. Vol. 7. St. Petersburg, 1791.\}

Путевые заметки 1868 - Путевые заметки П. И. Пашино. М., 1868. \{P. I. Pashino's Travel notes. Moscow, 1868.\}

Радлов 1899 - Радлов В. В. Опыт словаря тюркских наречий. Versuch eines Wörterbuches der Türk-Dialecte: Т. II. Согласные: k, к, к, Р, r, (亡́), х, h, ђ. СПб., 1899 \{Radloff $V$. V. Experience of the dictionary of Turkic dialects. Versuch eines Wörterbuches der Türk-Dialecte: Vol. II. Consonants: k, k, ќ, P, r, (亡́), x, h, ђ. St. Petersburg, 1899.\}

Самойлович 1927 - Самойлович А. О слове «казак» // Материалы особого комитета по исследованию союзных и автономных республик. Вып. 2. Л., 1927. С. 5-16. \{Samoilovich A. About the word "Kazak" // Materials of a special committee for the study of Union union and autonomous republics. Vol. 2. Leningrad, 1927. P. 5-16.\}

Сборник 1895 - Сборник Императорского Русского исторического общества. Т. 95. Памятники дипломатических сношений Древней России с державами иностранными. Памятники дипломатических сношений Московского государства с Крымскою и Нагайскою Ордами и с Турцией. Т. II. СПб., 1895. \{The collection of the Imperial Russian Historical Society. Vol. 95. The monuments of diplomatic relations of Old Russia with the foreign states. The monuments of diplomatic relations of the Muscovite state with the Crimean Horde, the Nogai Horde and Turkey. Vol. II. St. Petersburg, 1895.\}

СМИЗО 1941 - Сборник материалов, относящихся к истории Золотой Орды. Т. ІІ. Извлечения из персидских сочинений, собранные В. Г. Тизенгаузеном и обработанные А. А. Ромаскевичем и С. Л. Волиным (СМИЗО). М.Л., 1941. \{Collection of materials related to the Golden Horde History. Vol. II. Extracts from Persian writings collected by V. G. Tiesenhausen and processed by A. A. Romaskevich and S. L. Volin. Moscow_Leningrad, 1941.\}

Сокровенное сказание 2015 - Сокровенное сказание / Чингисхан. М., 2015. \{The secret legend / Chingishan. Moscow, 2015.\}

Султанов 1982 - Султанов Т. И. Кочевые племена Приаралья в XV-XVII вв. (вопросы этнической и социальной истории). М, 1982. \{Sultanov T. I. Nomadic tribes of the Aral sea region from the 15 th to the 17 th centuries (issues of ethnic and social history). Moscow, 1982.\}

Тарих-и Рашиди 2004 - Тарих-и Рашиди талиф-и Мирза Мухаммад Хайдар Дуглат. Чап-е аввал. Техран, 1383 (2004). \{The Tarikh-i-Rashidi (History of Rashid) of Mirza Muhammad Haidar Dughlat. 1st edition. Teheran, 1383 (2004).\}

Тарих-и Хабиб ас-сийар 2001-2002 - Тарих-и Хабиб ас-сийар фи ахбар афрад ал-башар талиф-и Гийас адДин ибн Хумам ад-Дин аль-Хусейни ал-мадувв ба-Хондемир. Чап-е чахаром. Джилд-и 4. Техран, 1380 (2001-2002). \{The Friend of Biographies in the news of the only among mortals of the Giias ad-Din ibn Humam ad-Din al'-Huseini nicknamed Khvandamir. $2^{\text {nd }}$ edition. Vol. 4. Teheran, 1380 (2001-2002).

Трепавлов 2002 - Трепавлов В. В. История Ногайской Орды. М., 2001. \{Trepavlov V. V. History of the Noghay Horde. Moscow, 2001.\}

Трепавлов 2019 - Трепавлов В. В. Шибаны: несостоявшийся этноним // Золотоордынское обозрение. 2019. T. 7, № 2. C. 351—371. \{Trepavlov V. V. The Shibans: A Failed Ethnonym. Zolotoordynskoe obozrenie $=$ Golden Horde Review. 2019. Vol. 7. No. 2. P. 351-371.\}

Туран 2008 - Туран на старинных картах: Образ пространства - Пространство образов. М., 2008. \{Turan on Vintage Maps: The Image of Space — The space of images. Moscow, 2008.\}

Тынышпаев 1993 - Tынышиаев М. История казахского народа. Алма-Ата, 1993. \{Tynyshpaev M. History of the Kazakh people. Alma-Ata, 1993.\}

Ускенбай 2012 - Ускенбай $К$. К проблеме аутентичного наименования Казахского государства позднего средневековья (на материалах «Михман-наме-йи Бухара» Ибн Рузбихана) // История Казахстана: итоги научных иссле- 
дований и презентация проекта десятитомной «Отан тарихы» / «История Отечества». Материалы Международной научно-практической конференции. Алматы, 2012. \{Uskenbay K. On the problem of the authentic name of the Kazakh state of the late Middle Ages (based on the materials of "Mikhman-name-yi Bukhara" by Ibn Ruzbihan) // History of Kazakhstan: results of scientific research and presentation of the ten-volume project "Otan tarikhi / History of the Fatherland". Materials of the international scientific and practical conference, Almaty, 2012.\}

Утемиш-хаджи 2017 - Утемиш-хаджи. Кара таварих / Транскрипция И. М. Миргалеева, Э. Г. Сайфетдиновой, 3. Т. Хафизова; пер. на рус. И. М. Миргалеева, Э. Г. Сайфетдиновой; общ. и науч. ред. И. М. Миргалеева. Казань, 2017. \{Utemish-Hadji. Kara Tavarih / Transcript by I. M. Mirgaleev, E. G. Saifetdinova, Z. T. Hafizov; Translation into Russian by I. M. Mirgaleev, E. G. Saifetdinova; Ed. by I. M. Mirgaleev. Kazan, 2017.\}

Эпистолярное наследие 2014 - Эпистолярное наследие казахской правящей элиты 1675-1821 годов. Сборник исторических документов в 2-х томах. Т. 1. Письма казахских правителей. 1675-1780 гг. Алматы, 2014. \{Epistolary heritage of the Kazakh ruling elite of 1675-1821. Collection of historical documents in 2 volumes. Vol. 1. Letters from Kazakh rulers. 1675-1780. Almaty, 2014.\}

Юдин 2001 - Юдин В. П. Центральная Азия в XIV - XVIII веках глазами востоковеда. Алматы, 2001. \{Yudin V. P. Central Asia in the $14^{\text {th }}-18^{\text {th }}$ centuries through the eyes of an orientalist. Almaty, 2001.\}

Gabain 1960 - Gabain Annemarie von. Kasakentum, eine soziologisch philologische Studie // Acta Orientalia Academiae Scientiarum Hungaricae. 1960. 11. S. 161-167.

Lee 2015 - Joo-Yup Lee. Qazaqliq, or Ambitious brigandage, and the formation of the Qazaqs. Studies in Persian cultural history. Vol. 8. Leiden; Boston, [2015].

Pritsak 2006 - Omeljan Pritsak. The Turkic Etymology of the Word "Qazaq" 'Cossack' / Harvard Ukrainian Studies. Vol. 28. No. 1/4. Rus' writ large: languages, histories, cultures: Essays presented in honor of Michael S. Flier on his sixtyfifth birthday (2006). P. 237-243. 